\title{
Effect of Surface Irrigation Regimes and Potassium Levels on Growth, Physiological Characters and Productivity of Fodder Beet (Beta vulgaris, L.) under Calcareous Soil Conditions
}

\author{
Mofeeda A. Seiam¹, Engy Samir Mohamed ${ }^{2}$, M.M. Attia ${ }^{3}$ and A.M.A. Abd El-Monem ${ }^{1}$ \\ ${ }^{1}$ Forage Crops Res. Department, Field Crops Institute. ARC, Egypt. \\ ${ }^{2}$ Crop physiology Res. Department, Field Institute. ARC, Egypt. \\ ${ }^{3}$ Soil, Water and Environment Res. Inst., ARC., Egypt.
}

\begin{abstract}
The present investigation was carried out in the farm of Nubaria Agricultural Research. Station during the two winter seasons $2016 / 2017$ and $2017 / 2018$ to study the effect of three surface irrigation treatments $\left(I_{1}=100 \%, I_{2}=80 \%, I_{3}=60 \%\right.$ of ETp) and four potassium levels (control $0,57.12,114.24$ and $171.36 \mathrm{~K}_{2} \mathrm{O} / \mathrm{ha}$ ) on fodder beet growth, physiological characters, productivity and forage quality under calcareous soil conductions. The main results were as follows:

1- Increasing irrigation levels up to $100 \%$ ETp led to significant increase in crop growth rate at the two periods (90-120) and (120-150 DAS), root diameter, leaf area per plant, root dry matter/ plant, root fresh weight/plant, total yield, crude protein percentage, digestive crude protein percentage, shoot $\mathrm{K} \%$, crude fiber percent and carbohydrate percent. There was insignificant difference between $100 \%$ and $80 \%$ ETp in leaves dry matter /plant, foliage fresh weight /plant, foliage yield (ton/ha) and $\mathrm{K} \%$ in root. Whereas the total digestible nutrient percent and root length were significantly increased by increasing water stress. Medium treatment at $80 \%$ of ETp give the maximum values of water use efficiency (WUE).

2- Increasing potassium fertilization levels up to $171.36 \mathrm{~kg} \mathrm{~K}_{2} \mathrm{O} /$ ha significantly increased CGR at (90-120 and 120-150 DAS), root length, root diameter, leaf area, root dry matter/plant, leaves dry matter/plant, $\mathrm{CP} \%, \mathrm{DCP} \%, \mathrm{CF} \%$ and carbohydrate \% In root. Adding 171.36 or $114.24 \mathrm{~kg} \mathrm{~K} 2 \mathrm{O} / \mathrm{ha}$ had insignificant differences in the first CGR period (90-120) DAS, root fresh weight (kg/plant), foliage fresh weight (g/plant), K\% in shoot and root. TDN (\%) decreased by increasing potassium fertilization levels. Maximum water use efficiency (WUE) was obtained when plants received $171.36 \mathrm{~kg} \mathrm{~K}_{2} \mathrm{O} / \mathrm{ha}$.

3- The interaction effect between water regime and potassium fertilization was found to be significant for CGR at the two periods, root length, leaf area/plant, leaves dry matter/plant, root and leaves fresh weight / plant, total yield, root yield, $\mathrm{CP} \%, \mathrm{DCP} \%, \mathrm{~K} \%$ in shoot and carbohydrate\% in the combined analysis. The maximum value of WUE was obtained when plants were watered by $80 \%$ from ETp and received $171.36 \mathrm{~kg} \mathrm{~K} 2 \mathrm{O} / \mathrm{ha}$.
\end{abstract}

Keywords: Fodder beet, water stress, potassium levels, physiological, growth characters, forage yield and quality.

\section{INTRODUCTION}

Fodder beet (Beta vulgaris, L.) is considered as one of the highest productive forage crops, and it is an ideal fodder for highs performance on dairy cows due to its nutritive value and high dry matter yield. Moreover, it is adapted to saline, calcareous soils and requires less water comared with other forage crops. On the other hand, the horizontal expansion of the new reclaimed areas requires the cultivation of crops offering source for satisfying incame to the farmers.

Irrigation is one of the most important factors, which has always played the greatest role in crop production. Water and fertilizers are two manageable inputs. Response to fertilizers dependson the level of available soil water and hence irrigation practices need to be modified to obtain maximum yields of fodder beet.

Hiekal (2008) used two different levels of irrigation water application, $100 \%$ and $70 \%$ of crop water requirements respectively, to irrigate fodder beet crop in calcareous loamy sand soil. Results, indicated that maximum average fresh yield (roots and tops) was 38.34 ton/fed, obtained by subsurface drip irrigation at $15 \mathrm{~cm}$ depth when $100 \%$ of water requirements was applied $\left(2387.3 \mathrm{~m}^{3} / \mathrm{fed}\right)$. Bahuri et al. (2003) found that fodder beet yield increased by increasing irrigation water and potassium rats. The fresh roots yield increased by 17.1 and $19.8 \%$ with increasing applied water from 2300 to $2760 \mathrm{~m}^{3} / \mathrm{fed}$, respectively compared with $1840 \mathrm{~m}^{3} / \mathrm{fed}$ irrigation treatment. Also, potassium fertilization recorded a significant effect. Plants characterized decrease in water content, osmotic potential and total water potential accompanied by loss of turgor, close of stomata and decrease in growth as well as decrease in photosynthesis process (Abd el Dayem et al., 2007). A common consequence of drought stress an increased production of reactive oxygen species (Ros) such as superoxide radical $\left(\mathrm{O}_{2}\right)$, hydrogen peroxide $\left(\mathrm{H}_{2} \mathrm{O}_{2}\right)$ and hydroxyl radical $(\mathrm{OH})$. These (Ros) are all toxic (Beyer and Frdovich, 1987) very reactive and cause severe damage to DNA, proteins and lipids (Bird et al., 1983). Decreasing soil water moisture significantly decreased root and leaves dry weight, root yield and total yield (Mofeeda et al., 2019). Also, Sakr et al., (2014) stated that water stress during maturity stage through withholding 
last, let two or last three irrigation markedly reduced forage yields and its component as well as crude protein $(\mathrm{CP} \%)$. In contrary, increased total soluble solids (TSS\%) and total digestible nutrients (TDN\%) were resulted from drought irrigation.

Potassium is one of the essential elements for plant nutrition and photosynthesis, translocation of photosynthates compounds, protein synthesis, control of ionic balance, regulation of plant stomata, water use, activation of plant enzymes and many others processes (Marschner 1995 and Reddya et al., 2004). Numerous studies have shown that application of $\mathrm{K}$ fertilizer mitigates the adverse effect of drought on plant growth (Andersen et al., 1992), Sangakkara et al., 2001, Hasan Zadeh et al., 2012, Kassab et al., 2012 and Mofeeda et al., 2019). The main objectives of this study were to test the effect of three surface irrigation treatments and four potassium fertilization levels on fodder beet growth, physiological characters, productivity, quality of forage and water use efficiency under calcareous soils conduction at Nubaria region.

\section{MATERIALS AND METHODS}

Two field experiments were conducted in the farm of Nubaria Agric. Res. Station during the two successive winter seasons of 2016/2017 and 2017/2018. The study was aimed to investigate the physiological response of fodder beet variety Voloshenger to water stress (under surface irrigation system) in combination with potassium application rates (control 0, 57.12, 114.24 and $171.36 \mathrm{Kg} \mathrm{K}_{2} \mathrm{O} / \mathrm{ha}$ ) at different levels of water supply. The adopted irrigation regimes were $I_{1}=100, I_{2}=80$ and $I_{3}=60 \%$ of the potential evapotranspiration (ETp), these represent optimum level of water supply (wet), moderate (medium) and severe water stress (dry), respectively.

In the two growing seasons, the amount of applied irrigation water was measured by a flow meter and it was calculated according to the following equation:

$\mathrm{AIW}=\frac{\mathrm{ETp}}{\mathrm{Ea}(1-\mathrm{LR})}$

Where: AIW = applied irrigation water depth (mm).

$\mathrm{ETp}=$ Potential evaporation $(\mathrm{mm})$ values obtained

by class A pan evaporation method (Doerenbos and Kassam, 1979) and calculated as follows:

$\mathrm{ETp}=\mathrm{E}_{\text {Pan }} \times \mathrm{K}_{\text {Pan }}$

Where: $\mathrm{E}_{\mathrm{Pan}}=$ daliy of measured A Pan Evaporation daily values ( $\mathrm{mm} /$ day)

$\mathrm{K}_{\mathrm{pan}}=$ Pan Coefficient. $\mathrm{K}_{\text {Pan }}$ values depend on the relative humidity, wind speed and the site conditions (bare or cultivated). A $\mathrm{K}_{\mathrm{pan}}$ value of 0.75 was used for the experimental site.

$\mathrm{Ea}=$ irrigation efficiency $(70 \%$ for surface irrigation system under experimental condition).

$\mathrm{LR}=$ leaching requirements (no additional water for leaching was added during the two growing seasons due to the low EC values of irrigation water and soil profile.

Water use efficiency (WUE) values were calculated according to Jensen (1983) as follows:

$\mathrm{WUE}=\frac{\text { Fodder beet total yield }(\mathrm{kg} / \mathrm{ha})}{\text { applied irrigation water }\left(\mathrm{m}^{3} / \mathrm{ha}\right)}$

Total yield $=$ root yield + foliage yield

Seeds of fodder beet, which were obtained from Agricultural Research Centre, were sown on $30 / 10 / 2016$ and $13 / 10 / 2017$ in both seasons respectively. Each plat area was $42 \mathrm{~m}^{2}(6 \times 7 \mathrm{~m})$ and included 6 ridges, $7 \mathrm{~m}$ long, $50 \mathrm{~cm}$ a part. All normal cultural practices of growing fodder beet in the location were followed. Phosphorus fertilizer was applied to the soil before sowing at the dose of $71.4 \mathrm{~kg} \mathrm{P}_{2} \mathrm{O}_{5} / \mathrm{ha}$ in the form of monocalcium superphosphate $\left(15.5 \% \mathrm{P}_{2} \mathrm{O}_{5}\right)$. Potassium treatments were applied at the levels of $0,57.12,114.24$ and $171.36 \mathrm{~kg} \mathrm{~K} 2 \mathrm{O} / \mathrm{ha}$ and ammonium nitrate $(33.5 \% \mathrm{~N})$ at the rate of $142.8 \mathrm{~kg} \mathrm{~N} / \mathrm{ha}$. The both four levels of potassium and ammonium nitrate were applied in two equal doses at 21 and 42 days after sowing.

The experimental design was a split plot in three replications. Irrigation regime were arranged in the main plots, whereas the potassium levels were randomly distributed in the sub-plots. Soil characteristics data of the experimental site are shown in Table (1).

Table 1: Soil characteristics of the experimental site

\begin{tabular}{|c|c|}
\hline * Particle size distribution & Value \\
\hline Sand $(\%)$ & 51.4 \\
\hline Silty $(\%)$ & 24.2 \\
\hline Clay $(\%)$ & 23.2 \\
\hline Texture & Sandy loam \\
\hline \multicolumn{2}{|l|}{ * Chemical character } \\
\hline Soil reaction $\mathrm{pH}(1: 2.5)$ & 7.95 \\
\hline Electric conductivity $(\mathrm{ds} / \mathrm{m})$ & 2.12 \\
\hline Organic matter $(\%)$ & 0.23 \\
\hline $\mathrm{CaCO}_{3} \%$ & 18.90 \\
\hline \multicolumn{2}{|c|}{ *Available macronutrients (mg/100g) } \\
\hline $\mathrm{N}$ & 35.50 \\
\hline $\mathrm{P}$ & 2.98 \\
\hline $\mathrm{K}$ & 120.8 \\
\hline \multicolumn{2}{|c|}{ *Available micronutrients (ppm) } \\
\hline $\mathrm{Fe}$ & 4.5 \\
\hline $\mathrm{Mn}$ & 2.71 \\
\hline $\mathrm{Zn}$ & 1.46 \\
\hline $\mathrm{Cu}$ & 1.06 \\
\hline
\end{tabular}

*Ec ds\m: soil paste

Soil organic matter, $\mathrm{CaCO}_{3}, \mathrm{EC}$ and $\mathrm{pH}$ were determined according to Black et al. (1982). Particle size distribution and soil moisture characters were determined as described by Blackmore (1972). Soil 
field'scapacity (FC) and wilting point (WP) of the soil at experimental site were determined on mass basis by a pressure extractor apparatus (LAB 023 LABORATORY). Available soil moisture (ASM) values were calculated and bulk density (BD) values were determined. The obtained results are presented in Table 2.

\section{Growth and physiological characters:}

To determine some growth traits, five plants were randomly taken from each plot at 90, 120 and 150 days after sowing (DAS). In each sample, plants were separated into their components leaves and roots, then dried at $60^{\circ} \mathrm{C}$ for $48 \mathrm{~h}$ in a ventilated oven to a constant weight to determine crop growth rate (CGR) at (90-120) and (120-150) DAS in g/plant/week according to Woston (1952) and calculated as follows:

$\mathrm{CGR}=\frac{W_{2}-W_{1}}{T_{2}-T_{1}}$

Where $\mathrm{W}_{2}-\mathrm{W}_{1}=$ differences in dry mater accumulation between two successive samples in grams.

$\mathrm{T}_{2}-\mathrm{T}_{1}=$ the number of days between two successive samples in weeks. Leaf area per plant $\left(\mathrm{cm}^{2}\right)$ was taken after 150 days from sowing $(\mathrm{LA}=25.43 \mathrm{x}$ dry weight of leaves per plant /dry weight of leaves disks. At harvesting time root length per plant $(\mathrm{cm})$, root diameter/plant $(\mathrm{cm})$, root dry matter (g/plant) leaves dry matter (g/plant), root fresh weight $(\mathrm{kg})$ and foliage fresh weight $(\mathrm{g})$ were determined.

\section{Fodder beet Yields}

At harvesting time, 200 days from sowing, each plot was harvested and weighed to determine the following data: total yield (ton/ha), root yield (ton/ha) and foliage yield (ton/ha).

\section{Chemical composition}

After 160 (DAS): - Crude protein (CP, \%) of root was determined according to A.O.A.C. (1990). Digesting crud Protein (DcP, \%) of roots

- DcP: [(CP × 0.9115) - 3.62] was determined according to Mcdonald et al. (1978).

- Potassium content (\%) of shoot and root: at harvesting time were determined according to Anton et al. (1995).
-Crud Fiber (CF\%) was determined of root according to A.O.A.C. (1990).

- Total carbohydrate of roots (\%) after 160 (DAS): Rroot samples were collected from each plot and dried in oven at $60^{\circ} \mathrm{C}$ for $48 \mathrm{~h}$ up to a constant weight, ground and prepared to determine total carbohydrate (\%) according to A.O.A.C. (1990).

- Total digestible nutrients (TDN \%) in root were calculated according to Church (1979).

\section{Statistical analysis}

The obtained data were analyzed with the appropriate method of statistical analysis of variance (ANOVA) as described by Gomez and Gomez (1984) using SAS (2014), and the means were compared using least significant differences (LSD test) at 0.05 level of probability. The combined analysis of variance was performed for the data of the two seasons after performing the test of homogeneity of error by Bartlet's test (Steel and Torrie 1980). The discussion of the results were carried out on the basis of combined analysis for two seasons except water relation.

\section{RESULTS AND DISCUSSION}

\section{Growth and Physiological Characters}

\section{Crop Growth Rate (CGR)}

Data in Table 3 represent the effect of irrigation regimes, i.e. 100,80 and $60 \%$ reference crop evapotranspiration(ETp), corresponding to 0, 57.15, 114.24 and $171.36 \mathrm{~kg} \mathrm{k} \mathrm{O} / \mathrm{ha}$. Results show that irrigation regimes,i.e, 100,80 and $60 \%$ reference crop evapotranspiration (ETp) on CGR at the first period (90-120) DAS and the secand period (120150) DAS recorded a significant effect. It can be noticed the CGR values were higher in the second period than the first period, such finding may be due to plants directed its effort in the second period for accumulate photosynthesiate compounds which increase dry matter accumulation. The maximum values of CGR at the two growth periods under study were obtained under the wet treatment which was watered with amount of water equals $100 \%$ of potential evapotranspiration (ETp). However, the minimum values were obtained from dry treatment $\left(\mathrm{I}_{3}\right)$ (irrigatied with amount of water equals $60 \%$ of potential evapotranspiration (ETp) in combined analysis.

Table 2: Field capacity, wilting point, available water and bulk density for soil of the experimental site at Nubaria Agric. Res. Station farm

\begin{tabular}{lcccc}
\hline $\begin{array}{l}\text { Soil depth } \\
(\mathbf{c m})\end{array}$ & $\begin{array}{c}\text { Field capacity } \\
(\mathbf{\%})\end{array}$ & $\begin{array}{c}\text { Wilting points } \\
(\mathbf{\%})\end{array}$ & $\begin{array}{c}\text { Available water } \\
(\boldsymbol{\%})\end{array}$ & $\begin{array}{c}\text { Bulk density } \\
\left(\mathbf{g} / \mathbf{c m}^{\mathbf{3}}\right)\end{array}$ \\
\hline $0-15$ & 24.60 & 13.53 & 11.07 & 1.17 \\
\hline $15-30$ & 24.70 & 13.42 & 11.28 & 1.20 \\
\hline $30-45$ & 23.90 & 12.99 & 10.91 & 1.22 \\
\hline $45-60$ & 23.60 & 12.83 & 10.77 & 1.25 \\
\hline Means & 24.27 & 13.19 & 11.08 & 1.21 \\
\hline
\end{tabular}




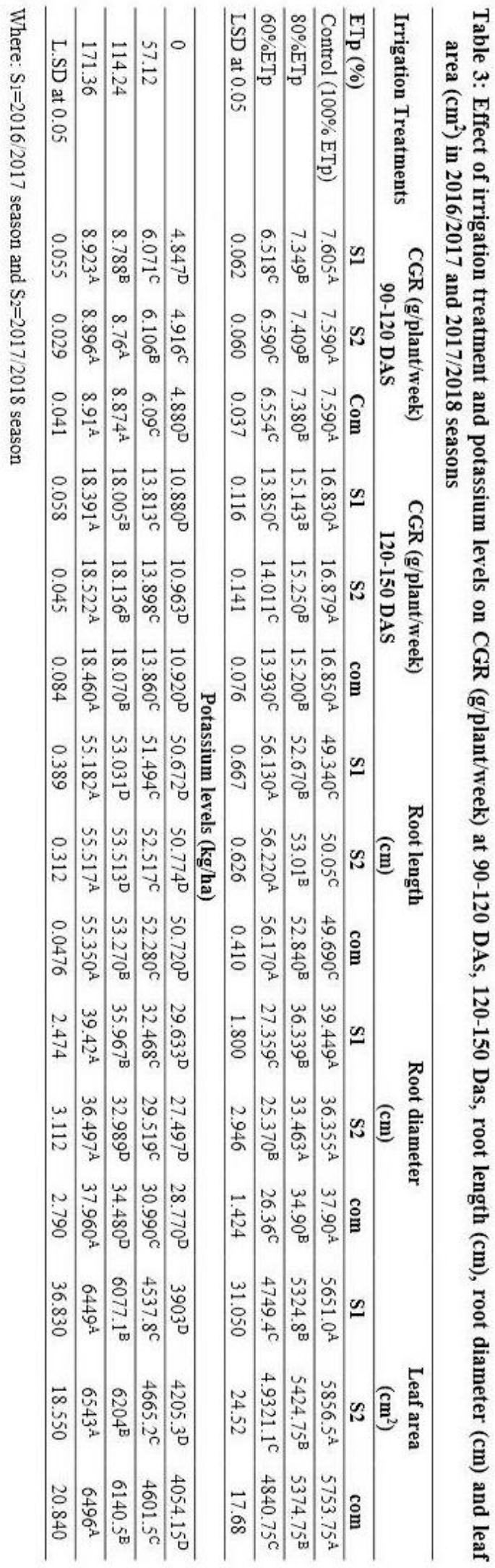


These results agreed with those reported by Abdallah and Yassen,(2008); Hussein et al., (2011) and Mofeeda et al.,(2019).

These finding may be due to the water stress condition have been found to disrupt dry matter accumulation or formation of photosynthesate compounds (Abdo, Fatma and Anton, 2009). Moreover, it was suggested that, at the drought stress level causes cellular shrink age of cells. cell membrane injury and production of free radicals that cause damage to the cellular apparatus (Terbea et al., 1995 and Sgherri et al., 1996). Similar results were obtained by Mary Henan (2011) on sunflower plants.

The effect of potassium fertilization, indicated that adding $171.36 \quad \mathrm{~kg} \quad \mathrm{~K}_{2} \mathrm{O} / \mathrm{ha}$ significantly increased (CGR at the second period compered by $114.24 \mathrm{Kg} \mathrm{K} \mathrm{K}_{2} \mathrm{O} / \mathrm{ha}$ but no significant at the first period in combined analysis. Such finding was attributed to significant regulatory roles of $\mathrm{K}$, in numerous plant. Physiological process via stomatal regulation, photosynthesis, nutrient balance and dry matter accumulation (Marschner, 2012).

Significant interaction between water treatments and potassium fertilization was recorded for CGR at the two periods under this study in both seasons and combined analysis as shown in Fig 1.

\section{Root length and Diameter $(\mathrm{cm})$}

Results in (Table 3) showed that water deficit increased significantly root length of fodder beet plant. Such results can be explained on the basis that as the upper soil dries, roots may grow deeper searching for water. These results are in line with Miseha et al.(1992) and Antonet al. (1995), who found that water stress increased root length of fodder beet plant. Table (2) show that increasing soil moisture stress decreased significantly root diameter of fodder beet would be restricted under dry conditions. It's worthy to mention that the fodder beet root which was less in diameter had greater in length. In this connection, Kramer (1969) and Anton et al.(1995) concluded that either an excess or a deficiency of soil water, limits root growth and functioning.

Table (3) show that the application of $171.36 \mathrm{~kg}$ $\mathrm{K}_{2} \mathrm{O} /$ ha increased significantly root length and root diameter. Such results may prove the importance of potassium for those crops which store carbohydrates like fodder beet plant. In other words, data indicated that fodder beet plant need an ample supply of potassium for good growth and high production, Romheld and Kirkby (2010) suggested that, increasing root growth, by applying $\mathrm{K}$ increases the root surface area under drought conditions, which ultimately enhances the water uptake by plant cells. Figure (1) shows, the significant effect of interaction between irrigation treatment and potassium fertilization levels on root length in combined analysis. The highest values of root length were obtained from water stress treatment equal $60 \%$ (I3) and received (171.36 $\left.\mathrm{kg} \mathrm{K}_{2} \mathrm{O} / \mathrm{ha}\right)$.

\section{Leaf area $\left(\mathrm{cm}^{2}\right)$}

Data from Table 3 show that leaf area (LA) was significantly affected by soil moisture stress. The wet treatment (I1) $100 \%$ of potential evopotranspiration ETP significantly increased leave area in both seasons and the combined analysis. Whereas, dry treatment (60\% of ETP (I3) resulted in the lowest values. Such reduction may be due to water deficit which induced a reduction in leaf area. These results are in harmony with those obtained by Saren et al. (2004) who found that irrigated sesame by four irrigations significantly increased LA I compared with one, two and three irrigations.

Concerning the effect of potassium fertilization on LA, plants treated with $171.36 \mathrm{~kg} \mathrm{~K}_{2} \mathrm{O} / \mathrm{ha}$ had the highest value of LA compared with other potassium treatments. Such finding may be due to the role of potassium in activating at least 60 different enzymes involved in plant growth (Roberd, 2005).

Figure (2) show the significant effect of interaction between water stress and potassium fertilization on LA $\left(\mathrm{cm}^{2}\right)$. The maximum values of LA was obtained from plants irrigated at $(100 \%$ ETP) in combination with adding potassium rate of (171.36 kg K $2 \mathrm{O} / \mathrm{ha}$ ).

\section{Root and leaves dry matter (g/plant)}

Results of Table 4 show that water stress significantly decreased root and leaves dry matter/plant as in combined analysis, wherease the $100 \%$ (ETP) and 80\% (ETP) treatments in leaves dry matter were higher than $60 \%$ ETP. Such results may indicate the importance of maintaining soil moisture at a high level for maximum accumulation of roots and leaves dry matter of fodder beet plant. In this respect Stanhill and Cohchron (1967) and Anton et al. (1995) concluded that there is a close relationship between decreasing soil water moisture and growth reduction of plant.

Data presented in Table 4 clearly show that the application of $171.36 \quad \mathrm{~kg} \quad \mathrm{~K}_{2} \mathrm{O} / \mathrm{ha}$ increased significantly root and leaves dry matter plant in the combined analysis. The application of potassium with 171.36 and114.24 $\mathrm{Kg} \mathrm{K}_{2} \mathrm{O}$ / ha had a significant differences on root and leaves dry matter/ plant. Abdel Hamid et al. (1992) and Anton et al. (1995) stated that foliar application of 400ppm potassium stimulated greatly the accumulation of dry matter in roots and leaves of fodder beet plant. Such result can be explained on the basis that potassium play an important role for accumulation of dry matter in the storage organs of plant. Such result can be explained on the basis that potassium play an important role for accumulation of dry matter in the storage organs of plant. 


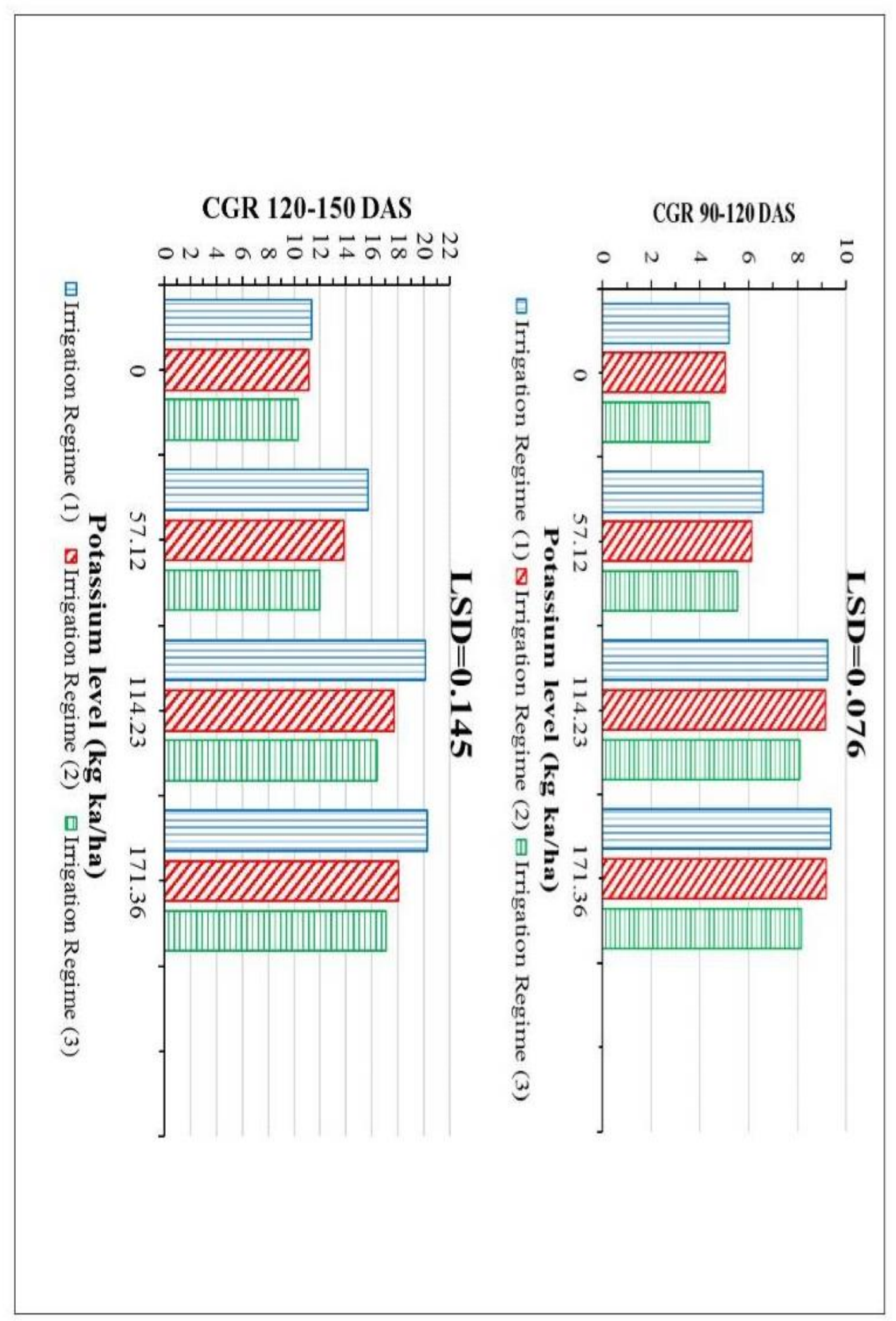




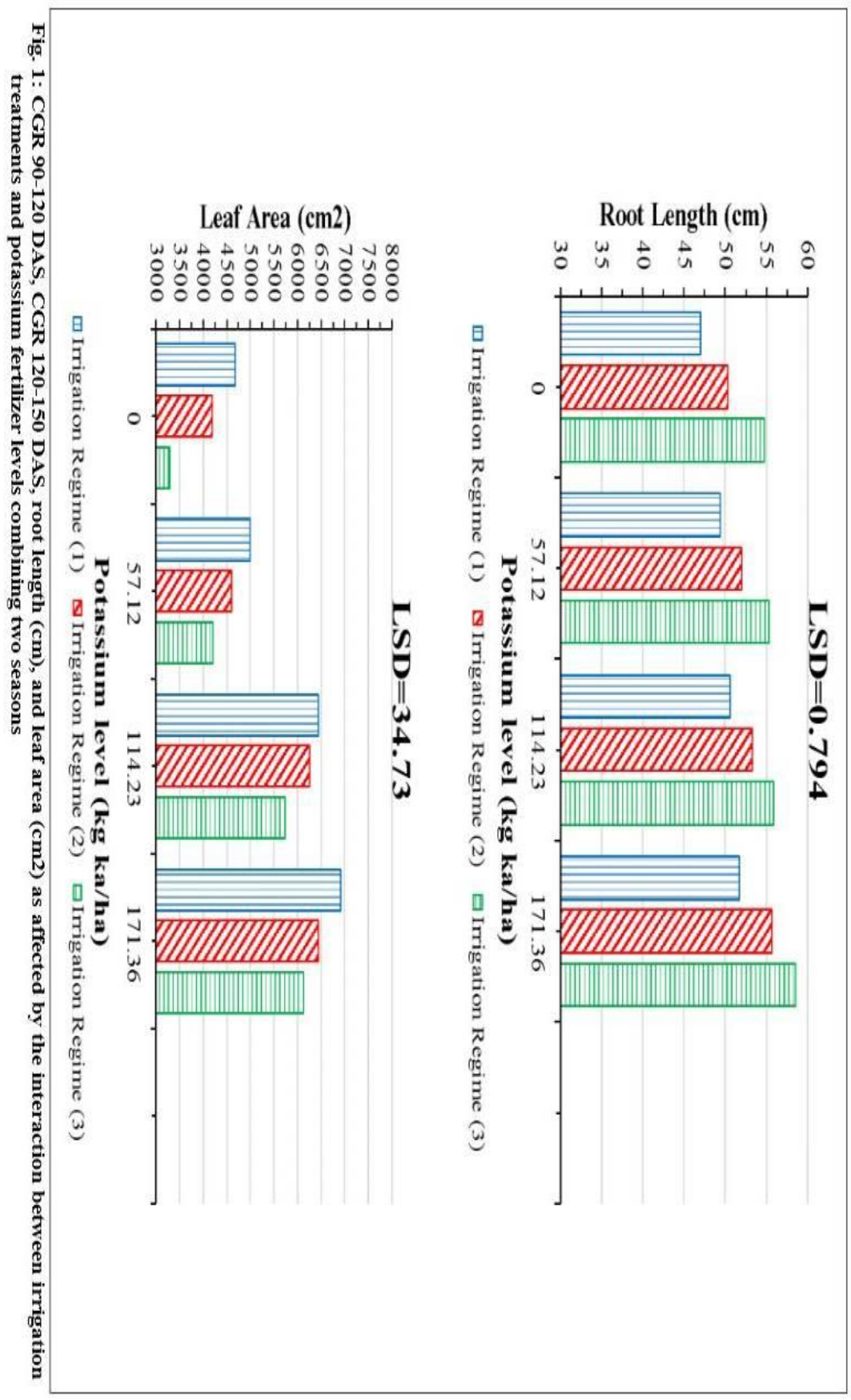




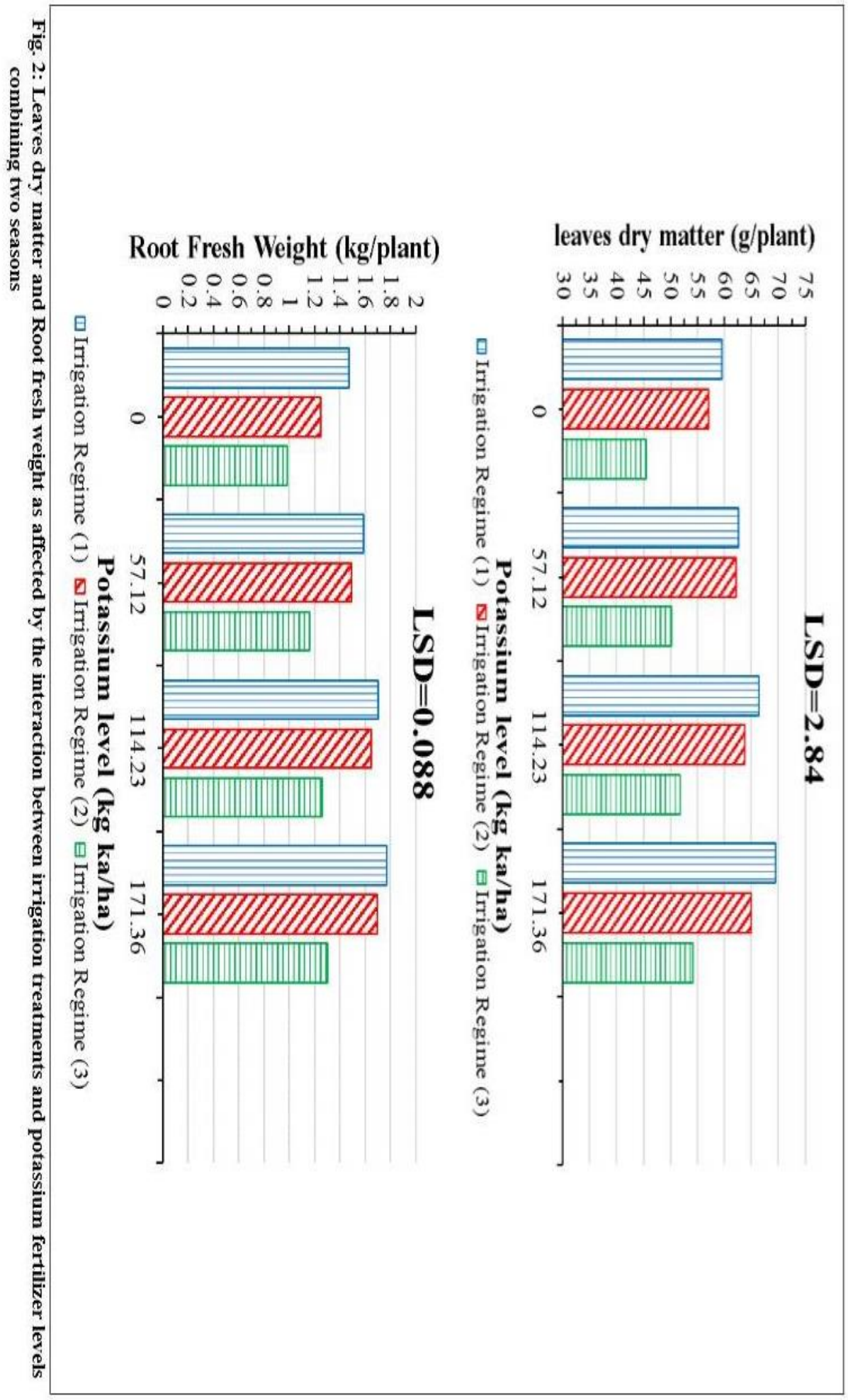




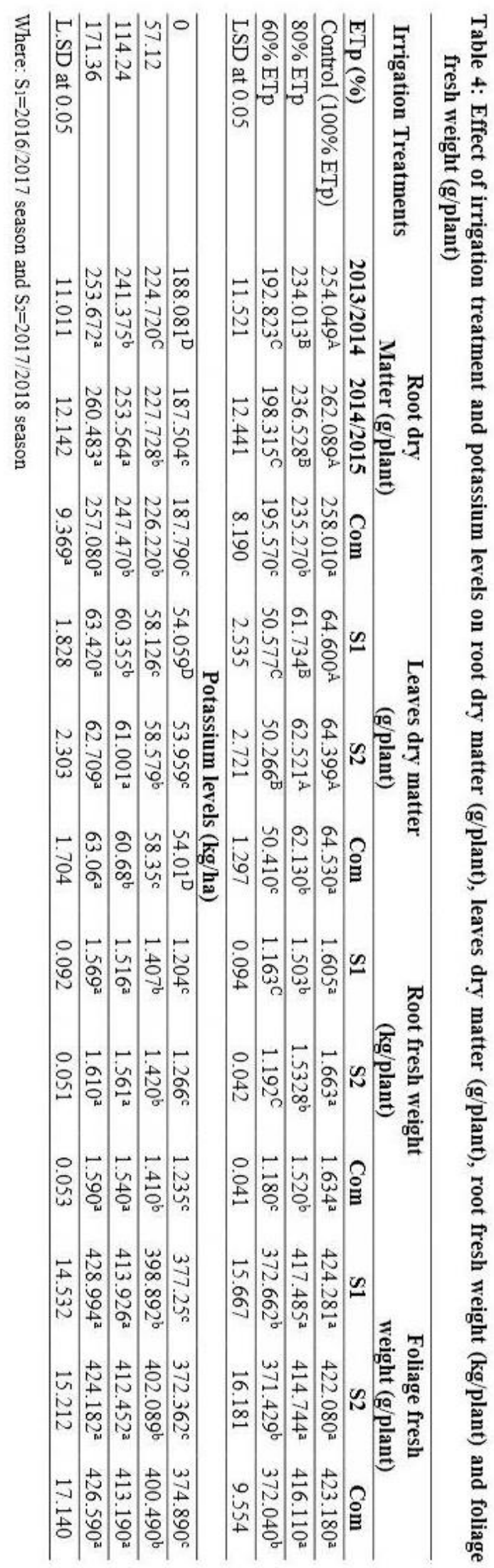


Data in Fig. 2 show that the interaction effect had insignificant effect on root dry matter/plant in but it was significant effect on leaves dry matter/plant. The maximum value of leaves dry matter/plant were obtained from plants irrigated at $(100 \%$ ETP) in combination with added $(171.36 \mathrm{~kg}$ $\mathrm{K}_{2} \mathrm{O} / \mathrm{ha}$ ).

\section{Root and Foliage fresh weight (g/ plant)}

Data in Table 4 showed that root and leaves fresh weight (kg/plant) decreased with increasing soil water moisture stress from $100 \%$ up to $60 \%$ ETP. On the reverse data indicated that the plants growing under (100\%) ETP and $80 \%$ of potential evapotranspiration ETP were obtained higher values compared to $60 \%$ ETP, respectively without significant differences between two treatments in foliage weight ( $\mathrm{g} / \mathrm{plant}$ ). Foyer and Noctor (2000) stated that drought stress inhibited photosynthetic activity in tissues due to the deficiency of water; one of the main factor in photosynthesis activity.

Concerning the effect of potassium fertilization on root and foliage fresh weight, plants treated with 171.36 and $114.24 \mathrm{~kg} \mathrm{~K} 2 \mathrm{O} / \mathrm{ha}$ had the highest value compared with other potassium treatments and without any significant differences between such two treatments. In this concern (Mofeeda et al., 2019), Tang et al.(2015) pointed that $\mathrm{K}$ indispensable mineral constituent, intrinsically playing a key role in plant growth and development process.

The interaction between water stress and potassium fertilization on root and leaves dry matter (g/plant) was found to be significant. There was no significant between plants irrigated with $100 \%$ (wet treatment) in combination with adding 171.36 and 114.24 $\mathrm{kg} \mathrm{K}_{2} \mathrm{O} /$ ha as shown in Fig. 2.

\section{Fodder beet Yields}

Data shown in Table 5 contain the effect of irrigation regimes; i.e. $100 \%, 80 \%$ and $60 \%$ reference crop evapotranspiration (ETP) on Fodder beet yields in combined analysis. Decreasing water amounts (water stress) led to substantial decreases in the aforementioned yield parameters. The present results showed root yield and total yield significantly affected by irrigation treatment in combined analysis. The maximum value was obtained when plants irrigated with amount of water $100 \%$ of $\mathrm{ET}_{\mathrm{P}}(54.81 \mathrm{ton} / \mathrm{ha})$ and $(65.70 \mathrm{ton} / \mathrm{ha})$ in combined analysis followed by irrigation treatment with amount of water equal $80 \%$ of $\left(E T_{P}\right)$. On the other hand there was insignificant differences between such two treatments for foliage yield (ton/ha) in combined analysis. The results reported here in this investigation coincided those previously obtained by Drawucatt and Messem (1977) and Mofeeda et al. (2019). Tagmetto et al. (2003) found that plots irrigated with surface drip irrigation produced the highest sugar beet yield, but furrow irrigation produced the lowest one.

However, Isoda et al. (2007) found that the irrigation led to an increase in the beet sugar yield due to an increase in the root yield. There was a slight reduction in the sugar content in roots. Human et al. (1990) and Hall et al. (1990) pointed out response to water stress conditions decrease to water stress conditions decrease photosynthesis and respiration.

As for the effect of potassium fertilization results indicated that applying $171.36 \mathrm{~kg} \mathrm{~K}_{2} \mathrm{O} /$ ha significantly increased total yield (ton/ha) and root yield (ton/ ha) compared with other potassium treatments. No significant differences were observed between such treatment $171.36 \quad \mathrm{~kg} \mathrm{~K} \mathrm{~K}_{2} \mathrm{O} / \mathrm{ha}$ and added $114.24 \mathrm{~kg}$ $\mathrm{K}_{2} \mathrm{O} / \mathrm{ha}$ with respect to foliage yield (ton/ha). These results could be ascribed to the enhanced effect of potassium on fodder beat growth which resulted in turn higher yield and its components. Tandon (1990) explained such results that potassium involves in the activation of large number of enzymes in the production and translocation of photosynthates compoineds from source to sink. These results are in harmony with those obtained by Mofeeda et al. (2019).

Also, the improvement of increasing potassium fertilization levels may be ascribed to the vital regulatory functions of potassium in photosynthesis process, photosynthesis translocation, improving the osmotic adjustment as well as activation of plant enzymes and antioxidant defense system (Sakr et al., 2014 and Hasanuzzaman et al., 2018 and Mofeeda et al., 2019).

Data in Fig.3 show the interaction effect between soil moisture stress and potassium fertilization was found to be significantly affected on total yield (ton/ha) and root yield (ton/ha). However, the maximum values of fodder beet yields were obtained when plants irrigated with amount of water equal $100 \%$ and $(80 \%)$ of ETP in combination with $171.36 \quad\left(\mathrm{~kg} \mathrm{~K}_{2} \mathrm{O} / \mathrm{ha}\right)$, respectively in the combined data.

\section{Chemical characters}

Tables 6 and 7 show that, CP\% DCP\% of root, $\mathrm{K} \%$ in shoot, $\mathrm{CF}$ and carbohydrate (\%) of root were significantly increased under wet conditions at (100\%ETP). On the other hand, plant irrigated plants wit (60\%ETP) give the highest value of (TDN\%). While, increasing water deficit to $80 \%$ ETP(medium treatment) in significantly decreased $\mathrm{K} \%$ in root at harvesting time. El-Kalla et al.(1985) explained the carbohydrates reduction under water stress conditions, that water shortage causes stomatal closure and this in turn prevents $\mathrm{CO}_{2}$ diffusion into the air inside the tissue of plants and consequently the photosynthetic efficiency becomes low. 


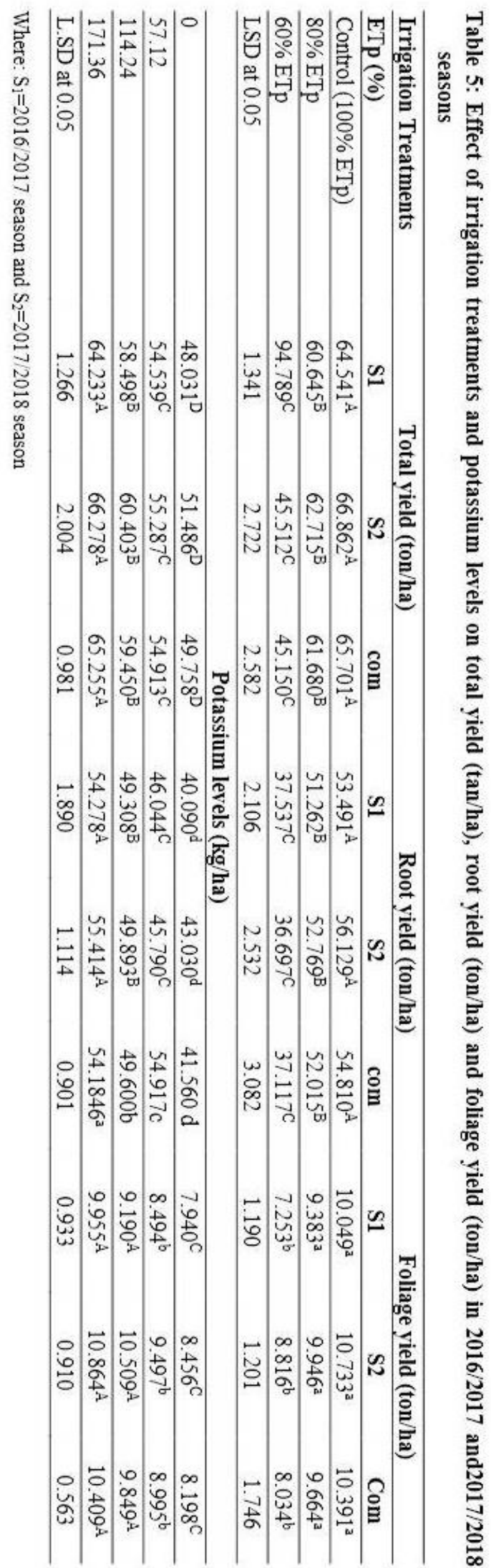




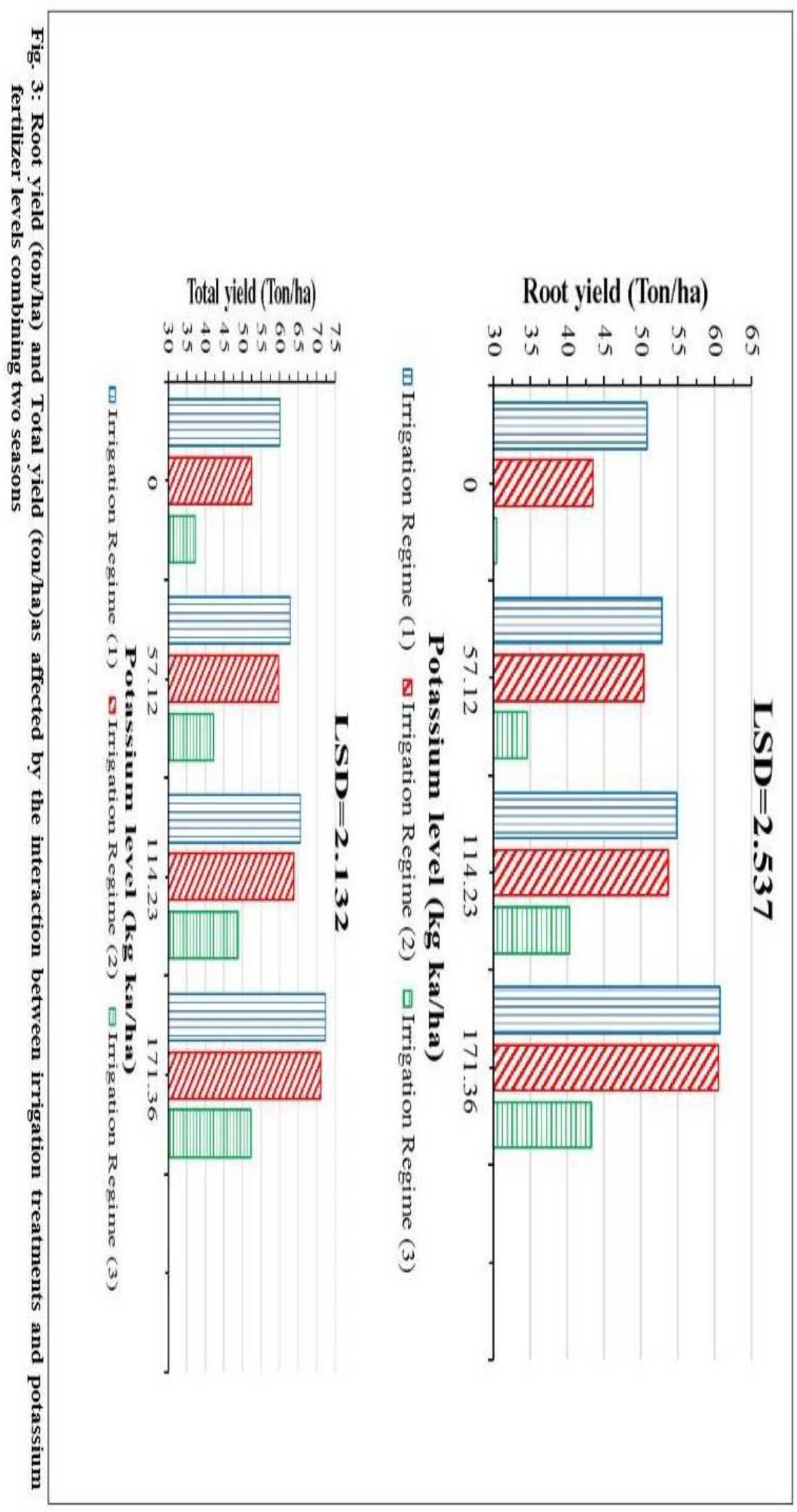




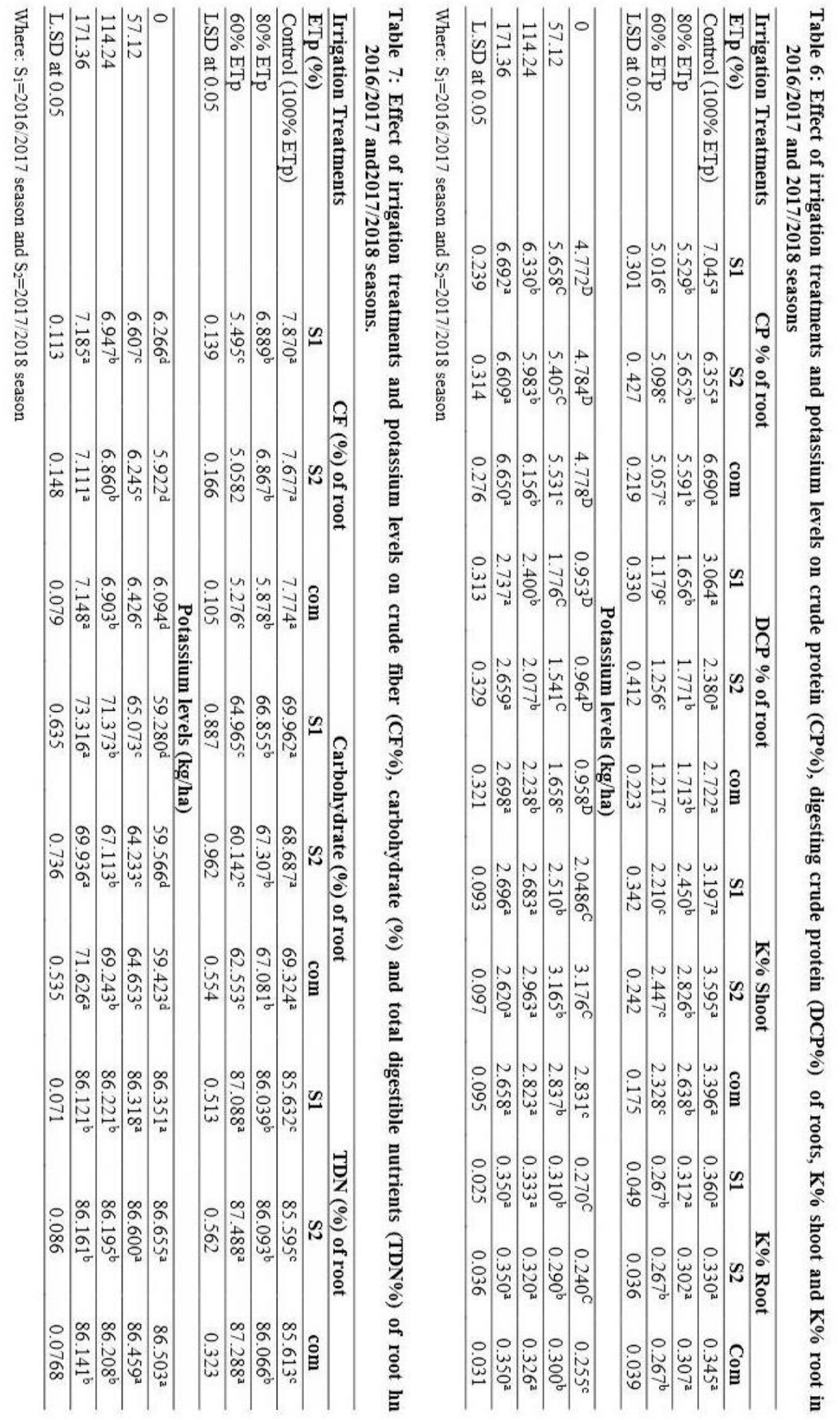


Similar results were obtained by Anton and El Raies (2000), who found that increasing soil moisture stress up to $70-75 \%$.in sandy soils decreased total carbohydrates of sesame seeds.

Concerning the effect of potassium fertilization, Table 7 indicated that treated fodder beet plants by $171.36 \mathrm{Kg} \mathrm{K} \mathrm{K}_{2} \mathrm{O} / \mathrm{ha}$ significantly increased CP\%, $\mathrm{DCP} \%, \mathrm{CF} \%$ of root and carbohydrate\% compared with all potassium levels but, there was insignificant increased $\mathrm{K} \%$ in shoot, root at harvesting time and TDN (\%) between such treatment and $114.24 \mathrm{Kg}$ $\mathrm{K}_{2} \mathrm{O} / \mathrm{ha}$. These finding maybe due to the role of potassium in enzymes activation involved in ATP production which is more important to regulating the rote of photosynthesis, sugar formation and translocation. These reported by Thakur and Patel (2003), Abdel-Aziz and El-Bialy (2004) and Mofeeda et al. (2019).

Fig. 4 indicated that the interaction effect between soil moisture stress and potassium fertilization recorded was significant effect on $\mathrm{CP} \%$, $\mathrm{DCP} \%$ in root, $\mathrm{K} \%$ in shoot and carbohydrate in root. The highest value of such traits were recorded from wet treatment (irrigated at $100 \mathrm{ETp}$ ) in combination with adding 171.36 and $114.24 \mathrm{~kg}$ $\mathrm{K}_{2} \mathrm{O} /$ ha, respectively. However, plants growth under dry treatment $(60 \%$ ETP) recorded highest value of TDN\% combination with control and $57.12 \mathrm{~kg}$ $\mathrm{K}_{2} \mathrm{O} / \mathrm{ha}$,

\section{Soil water relations:}

\section{Potential evapotranspiration (ETp)}

Monthly potential evapotranspiration (ETp) values measured by class A pan method are presented in Table 8. Results showed that daily (ETp) values were low during December and January and increased to maximum values during May of both seasons.

\section{Amount of applied irrigation water (AIW)}

Monthly and total applied of irrigation water by surface irrigation system to the fodder beet according to the different irrigation treatments for two growing seasons are presented in Table 9.

Table 8: Potential evapotranspiration, ETp $(\mathrm{mm} / \mathrm{day})$ and $(\mathrm{mm} / \mathrm{month})$ during the two growing seasons

\begin{tabular}{lcccc}
\hline \multirow{2}{*}{ Month } & \multicolumn{2}{c}{$\mathbf{2 0 1 6 / 2 0 1 7}$} & \multicolumn{2}{c}{$\mathbf{2 0 1 7 / 2 0 1 8}$} \\
\cline { 2 - 5 } & $\mathbf{m m} / \mathbf{m o n t h}$ & $\mathbf{m m} / \mathbf{d a y}$ & $\mathbf{m m} / \mathbf{m o n t h}$ & $\mathbf{m m} / \mathbf{d a y}$ \\
\hline Oct. & -- & -- & 48.45 & 2.85 \\
\hline Nov. & 44.32 & 1.47 & 54.00 & 1.80 \\
\hline Dec. & 34.87 & 1.12 & 41.85 & 1.35 \\
\hline Jan. & 29.06 & 0.93 & 34.87 & 1.12 \\
\hline Feb. & 33.71 & 1.16 & 41.32 & 1.42 \\
\hline Mar. & 54.09 & 18.80 & 67.42 & 2.17 \\
\hline Apr. & 81.00 & 2.70 & 101.25 & 3.37 \\
\hline May & 99.45 & 3.31 & 121.50 & 4.05 \\
\hline Jun & 53.43 & 3.56 & -- & -- \\
\hline Total & 429.93 & & 510.66 & \\
\hline
\end{tabular}

Table 9: Amounts of applied irrigation water $\left(\mathrm{mm}, \mathrm{m}^{3} / \mathrm{fed}\right.$. and $\left.\mathrm{m}^{3} / \mathrm{ha}\right)$ as affected by irrigation treatments

\begin{tabular}{lcccccc}
\hline \multirow{2}{*}{ Months } & \multicolumn{3}{c}{$\begin{array}{c}\mathbf{2 0 1 6} / \mathbf{2 0 1 7} \\
\text { Irrigation treatments }\end{array}$} & \multicolumn{3}{c}{$\begin{array}{c}\mathbf{2 0 1 7 / 2 0 1 8} \\
\text { Irrigation treatments }\end{array}$} \\
\cline { 2 - 7 } & $\mathbf{1 0 0 \% \text { ETp }}$ & $\mathbf{8 0 \% \text { ETp }}$ & $\mathbf{6 0 \% \text { ETp }}$ & $\mathbf{1 0 0 \% \text { ETp }}$ & $\mathbf{8 0 \% \text { ETp }}$ & $\mathbf{6 0 \% \text { ETp }}$ \\
\hline Oct. & -- & -- & -- & 69.21 & 69.21 & 69.21 \\
\hline Nov. & 63.31 & 63.31 & 63.31 & 77.14 & 61.71 & 46.28 \\
\hline Dec & 49.81 & 39.84 & 29.88 & 59.78 & 47.82 & 35.86 \\
\hline Jan. & 41.51 & 33.20 & 24.90 & 49.81 & 39.84 & 29.88 \\
\hline Feb. & 48.15 & 38.52 & 28.89 & 59.02 & 47.21 & 35.41 \\
\hline Mar. & 77.27 & 61.81 & 46.36 & 96.31 & 77.04 & 57.78 \\
\hline Apr. & 115.51 & 92.56 & 69.42 & 144.64 & 115.71 & 86.78 \\
\hline May & 142.27 & 113.65 & 85.24 & 173.57 & 138.85 & 104.14 \\
\hline Jun. & 76.32 & 61.05 & 45.79 & -- & -- & -- \\
\hline Total $(\mathrm{mm})$ & 614.15 & 503.94 & 393.79 & 729.48 & 597.39 & 465.34 \\
\hline $\mathrm{m}^{3} /$ fed & 2579.43 & 2116.54 & 1653.91 & 3063.81 & 2509.03 & 1954.42 \\
\hline $\mathrm{m}^{3} / \mathrm{ha}$ & 6139.04 & 5037.36 & 3936.30 & 7291.86 & 5971.49 & 4651.51 \\
\hline
\end{tabular}




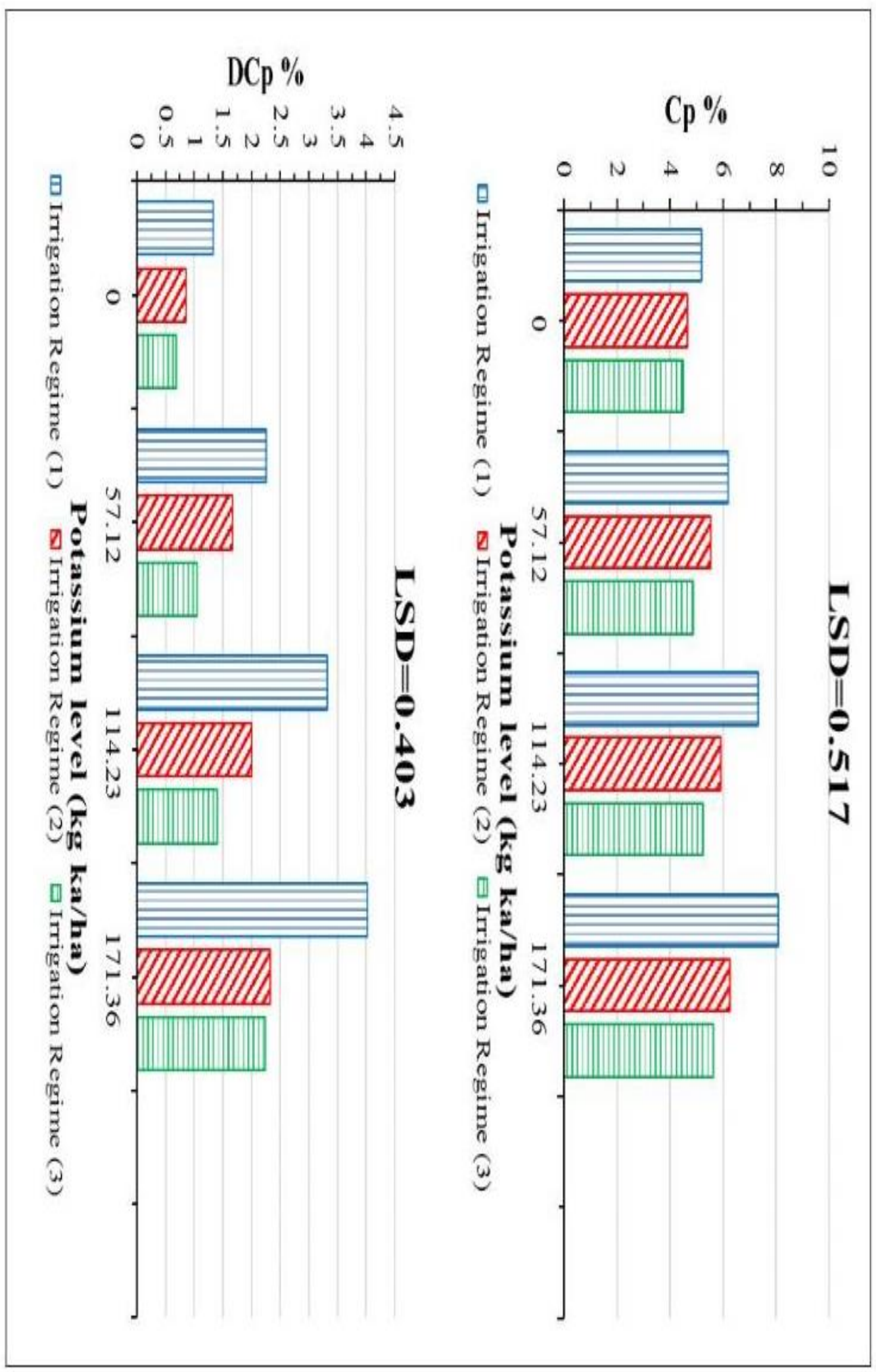




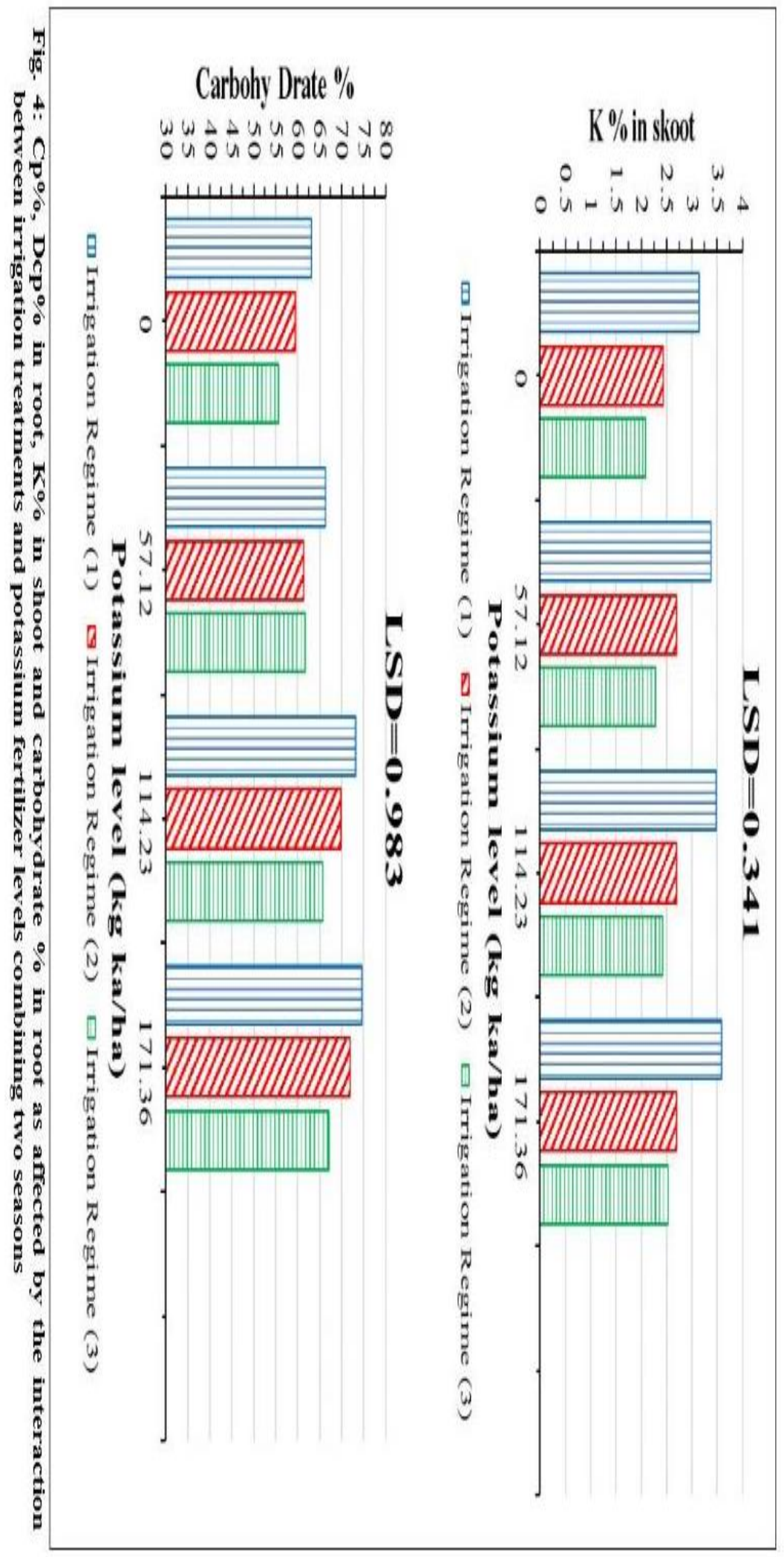


Results showed that the total amount of applied irrigation water for 100, 80 and $60 \%$ of ETp irrigation treatments were 6139.04, 5037.36 and $3936.30 \mathrm{~m}^{3} / \mathrm{ha}$ in the first season, while they were $7291.86,5971.49$ and $4651.51 \mathrm{~m}^{3} / \mathrm{ha}$ in the second season, respectively. Differences in the amount of applied irrigation water between the two successive seasons due to differences in climatic conditions. Results showed the normal trend of increasing applied irrigation water with the advance in plant growth and decrease at the ripening stage. The obtained results agreed with those of Doorenbos and Kassam (1979) and Bahuri et al. (2003).

Water use efficiency (WUE):

The effect of surface irrigation regime and Potassium treatments on water utilization efficiency as $\mathrm{Kg}$ of fodder beet total yield per cubicmeter of applied water per ha during the two growing seasons is presented in Table10.

The results showed that WUE values were $10.34,12.08$ and $11.37 \mathrm{Kg}$ in the first season and they were $9.16,10.50$ and $9.77 \mathrm{~kg}$ fodder beet total yield in the second season for irrigation treatments $\mathrm{I}_{1}, \mathrm{I}_{2}$ and $\mathrm{I}_{3}$, respectively.

It is clear from the results that WUE values from first season were higher than those from the second season due to less amount of applied irrigation water was added in the first season. The reduction in WUE value for $I_{1}$ irrigation treatment as compared to that for $\mathrm{I}_{3}$ indicates decrease in water use efficiency with increasing applied irrigation water for $\mathrm{I}_{1}$.
Also, the results indicated that the values of WUE increased with increasing the rate of potassium fertilization for all irrigation treatments in the two growing seasons.

The results also, showed that higher WUtE values were obtained from interaction of $\mathrm{I}_{2}$ and potassium fertilizer rate $\left(171.36 \mathrm{~kg} \mathrm{~K}_{2} \mathrm{O} / \mathrm{ha}\right)$ in both seasons. The highest value of WUtE recorded 13.78 and $12.18 \mathrm{~kg}$ fodder beet total yield $/ \mathrm{m}^{3}$ applied water were obtained from $\mathrm{I}_{2}$ irrigation treatment and from potassium fertilizer rate $\left(171.36 \mathrm{~kg} \mathrm{~K}_{2} \mathrm{O} / \mathrm{ha}\right)$ in the two growing seasons, respectively.

The results are in agreement with these reported by Doorenbos and Kassam (1979). Results agree also with those of Kassab et al. (2012) who showed that water use efficiency of fodder beet plants increased significantly by decreasing the irrigation level (water stress). Foliar K spray of $1 \mathrm{~kg} / \mathrm{fed}$, gave the highest values of growth and yield parameters as well as WUE in both seasons.

\section{CONCLUSION}

In the light of the present results, it clearly that the maximum fodder beet yield and quality were obtained from wet treatment (irrigated with $100 \%$ ETp) plus potassium fertilization level of 171.36 $\mathrm{kg} / \mathrm{K}_{2} \mathrm{O} / \mathrm{ha}$ followed by medium treatment $(80 \%$ ETp) and the same level of potassium fertilization.

On the other hand, the maximum value of WUE ( $\mathrm{kg}$ total yield $/ \mathrm{m}^{3}$ applied water) was obtained under $\mathrm{I}_{2}(80 \% \mathrm{ETp})$ and potassium fertilization level of $171.3 \mathrm{~kg} / \mathrm{ha}$.

Table 10: Mean water utilization efficiency (WUE) values for fodder beet as affected by irrigation treatments and potassium levels during two growing seasons

\begin{tabular}{|c|c|c|c|}
\hline \multirow{2}{*}{ Irrigation Treatments } & \multicolumn{3}{|c|}{ WUE } \\
\hline & Potassium levels kg/ha & $2016 / 2017$ & $2017 / 2018$ \\
\hline \multirow{4}{*}{$100 \% \operatorname{ETp}\left(\mathrm{I}_{1}\right)$} & 0 & 9.51 & 8.47 \\
\hline & 57.12 & 10.13 & 8.77 \\
\hline & 114.24 & 10.43 & 9.20 \\
\hline & 171.36 & 11.42 & 10.22 \\
\hline Mean & & 10.34 & 9.16 \\
\hline \multirow{4}{*}{$80 \% \operatorname{ETp}\left(\mathrm{I}_{2}\right)$} & 0 & 10.25 & 8.93 \\
\hline & 57.12 & 11.77 & 10.07 \\
\hline & 114.24 & 12.54 & 10.82 \\
\hline & 171.36 & 13.78 & 12.18 \\
\hline Mean & & 12.08 & 10.50 \\
\hline \multirow{4}{*}{$60 \% \operatorname{ETp}\left(I_{3}\right)$} & 0 & 8.90 & 8.46 \\
\hline & 57.12 & 10.85 & 8.95 \\
\hline & 114.24 & 12.26 & 10.62 \\
\hline & 171.36 & 13.49 & 11.08 \\
\hline Mean & & 11.37 & 9.77 \\
\hline \multirow{4}{*}{$\begin{array}{l}\text { General mean of } \\
\text { Potassium fertilization }\end{array}$} & 0 & 9.55 & 8.62 \\
\hline & 57.12 & 10.92 & 9.26 \\
\hline & 114.24 & 11.74 & 10.21 \\
\hline & 171.36 & 12.90 & 11.16 \\
\hline
\end{tabular}


Therefore, under calcareous soil condition and surface irrigation regimes of $80 \%$ ETp in combination with adding $171.36 \mathrm{Kg} \mathrm{K} \mathrm{K}_{2} \mathrm{O} / \mathrm{ha}$ it is recommended that about $20 \%$ of amounts applied irrigation water could be saved with insignificant decreasing in total fodder beet yield.

\section{REFERENCES}

A.O.A.C. 1990. Official methods of analysis $15^{\text {th }}$ Ed., Association of Official Agriculture Chemists. Washington, D.C., USA, pp: 770771.

Abdallah, E.F. and A.A. Yassen, 2008. Fodder beet productivity under fertilization treatments and water augmentation. Aust. J. Basic \& Appl. Sci., 2(2): 282-287.

Abdel-Aziz, El-Set A. and U.S. El-Bialy (2004). Response of maize plant to soil moisture stress and oliar spray with potassium. J. Agric. Sci., Mansoura Univ. 29(6): 3599-3619.

Abdel-Dayem, H.M. and Faten, H.M. and Fatem. H.M. (2007). Effect of potassium and boron on drought totlerance of cotton plants, conferences Hall, Faculty of Agriculture Mansoura University, pp. 141-152.

Abdel-Hamid, M.F.; W.I. Miseha; M.M. Bassiem and N.A. Anton (1992). Response of fodder beet to some elements. Fifth Egyptian Botanical Conference, Saint Catherine, Sinai, Egypt, April 28-30, 1992, 307-322.

Abdo-Fatma, A. and N.A Anton (2009). Physiological response of sesame to soil moisture stress and potassium fertilization in sandy soil. Fayoum J. Agric. Res. \& Dev., Vol. 23, No.(1)88-111..

Andersen, M.N., C.R. Jense, R. Losch (1992). The interaction effect of potassium and drought in field grown barley. I. Yield, water-use efficiency and growth. Soil Plant Sci., 42-4344.

Anton, N.A. and A.A.M. El-Raies (2000). Response of sesame to soil moisture stress and nitrogen fertilization in sandy soil Egypt. J. APPI. Sci., 15(7): 360-377.

Anton, N.A., F.A. Abbas, K.M.R. Yousef and ElHyatemy (1995). Effect of irrigation intervals and potassium fertilization on fodder beet plant under calcareous soil conditions. Egypt J. Appl. Sci., 10(12): 404-453.

Bahuri, S.S., A.A. Camal and A.A. Wilod (2003). Effect of irrigation water amount and potassium realization on fodder beet yield and yield components under new reclaimed sandy soil conditions. Po. $10^{\text {th }}$ Conf. Agron., Suez. Camal Univ., Fac. Environ., Agric. Sci., El Arish, Egypt. 2003.
Beyer, W.F. and I. Frdovich (1987). Assaying for superoxide dismutase activity: some large consequences of minor changes it conditions. Analytical Biochemistry, 161: 559-566.

Bird, B.R., S.S.O. Hungo, M. Hadley, H.H. Draper (1983). Determination of malondealdehdre in biological matrices. Free. Rad. Mio. Med., 27: 647-666.

Black, C.A.; D.D. Evan;, L.E. Ensminger; G.L. White and F.E. Clarck, (1982). Methods of soil analysis parts. Agron. Inc., Madison, Wisc.

Blackmore, L.C. (1972). Methods for chemical analysis of soils. Newzealand Soil Durean. Rep. No. 10.

Church, D.C. (1979). Digestive physiology and Nutrition of ruminant, 1 Corvallis, O \& B Books Inc.

Doerenbos, J. and Akassam (1979). Yield response to water by, FAO irrigation and drainage paper No. 33, Rome, Italy.

Drawucatt. A.P.and A.B. Messem (1977). Response by sugar beet to irrigation, 1965-75. The Journal of Agricultural Science, 89: 481-495.

El-Kalla, S.E.; M.H. El-Hindi; A.S. Hanna and N.g. Ainer (1985). Maize growth, yield and yield components and chemical of grains as affected by different irrigation levels and plant population. Agric. Res. Rev. 63 (7): 167-176.

Foyer, C.H. and G. Noctor (2000). Oxygen processing in photosynthesis: regulation and signaling. New Photo. 146: 359-388.

Gomez, K.A. and A.A. Gomez (1984). Statistical Procedures for Agricultural Research. AwileyInter Sciences Publication, John Wiley and Sons, Inc., New York, USA.

Hall, A.J.; D.J. Conner and D. M. Whitifield (1990). Root respiration during grain filling in sunflower: The effect of water stress. Plant Soil, 121: $57-66$.

Hasanuzzaman, M.; M.H.M Borhannelddin Bhryan; Kamrun Nahar; Md. Shahadat Hossain, Juhayer Al Mahmud, Md. Shahadat Hossan, Abdul Awal Chowdhury Masud, Mounita and Masayuki Fujita (2018). A Vitol Regulator of Plant Responses and Tolerance to Abiotic Stresses. Agronomy Review, 8 (31): 1-29.

Hasan Zadeh, A.M., G. Sepanloa and M.A. Bahmanyar (2012). Effect of potassium and manure fertilizers on concentration of Microelements in leaf and grain of wheat under water stress European Journal of Experimental Biology, 2(3): 520-524.

Hiekal, H.A.M (2008). Efficiency of irrigation systems under water deficit conditions in salne calcareous soils. Agricultural mechanization and engineering between existing and prospected: 459-476. The $15^{\text {th }}$, Annual Conference of Misr Society of Ag. Eng., 12-13 March, 2008. 
Human, J.J., D. Dutoit, H.D.Be zuidenout and L.P. Bruyn (1990). The influence of plant water stress on net photosynthesis and with holding irrigation. J. of Sci and Res. (JSR) 3117-3126.

Hussein, M.M., M.M. Shaaban, A.M. Elsaady and A.A. El-Sayed, (2011). Growth and photosynthetic pigments of fodder beet plants as affected by water regime and boron foliar fertilization. Nature and Science, 9 (1).

Isoda, A., H. Konishi and P. Wanga (2007). Effect of different irrigation metods on yield and water use efficieney of sugar beet (Beto vulgaris) in the arid area of China. Hort. Research Chiba University (Japan). 61: 7-10.

Jensen M.E. (1983). Design and operation of farm irrigation systems, Amer. Soc. Agric. Eng. Michigan, USA, p. 827.

Kassab, O.M., Orabi, S.A. and Abo Elllil, A.A. (2012). Physiological response to potassium application in fodder beet plant grown under water stress. Australian Journal of Basic and Applied Science, 6 (13): 566-574.

Kramer, P.J. (1969). Plant and water relationships a modern synthesis, Tata. MacGraw-Hill Publishing Company Ltd., New Delhi. 482pp.

Marschner, H. (1995). Mineral nutrition of higher plants. Academic Press San Diego, U.S.A.

Marschner, H., (2012). Marschner's Mineral Nutrition of Higher plants, $3^{\text {rd }}$ ed. Academic Press: London, U.K. 2012: 178-189.

Mary, E., N. Henen (2011). Response of some sunflower to water stress and biofertilization. $\mathrm{Ph}$ D. Thesis Fac. Of Agri. Alex. Univ.

Mcdonald, P.R. A. Edward and J.F. Greenhalgh (1978). Animal Nutrition. Longman Groupu, London, U.K.

Miseha, W. I.; M.F. Abdelhamid and N. A. Anton (1992). Effect of water deficit on growth and yield of fodder beet plant. Fifth Egyptian Botanical Conference, Saint Catherine, Sinai, Egypt. April 28-30: 195-208.

Mofeeda, A.Seiam. Mary E. Nash, Osman A.M. and M.A. Sayed (2019). Productivity and physiological response of fodder beet to drip irrigation regimes and potassium levels under calcareous Soil Condition. Alex. J. Agric., Sci. 6(64): 439-458.

Reddya, A.R., K.v. Chaitanya, M. Vivekanandanb, (2004). Drought-induced responses of photosynthesis and antioxidant metabolism in higher plants. J. Plant Physiol., 161: 1189-1202.

Robed, P.H. (2005). The role of potassium agua botanic, p.1-6.

Romheld, V. and E. A. Kirkby, 2010 Research on potassium in agriculture. Needs and prospects. Plants Soil, 334: 155-180.
Sakr. O., H.A. Awad, S.E. Seadh and W.E.E. Abido (2014). Influence of irrigation withholding and potassium levels on forage yields and its quality of fodder beet. J. Cro. Sci. 5(1): 116-125.

Sangakkara, U.R. M. Frehner and J. Nosberger (2001). Influence of soil moisture and fertilizer potassium on the vegetative growth of mungbean (Vigna radiate L. wilczek) and cowpea (Vigna unguiculata L. walp). J. Agron. Crop. Sci., 186: 73-81.

Saren, B.K.; S. Tudu and P. Nandi (2004). Effect of irrigation and Sulphur on growth and productivity of summer sesame (Seasamum indicum L.) Madras Agric., J. 91 (1-4): 56-60.

Sgherri, C.L.M., C. Pinzino, and F. Navari-Lzzo (1996). Sunflkower seedling subjected to increasing stress by water deficit: changes in $\mathrm{O}_{2}$ production related to the composition of thylakoid membranes. Plant Phys. 196 (3): 446452.

Stanhill, G.W. and W.G. Cohchron (1967). Statistical Methods, $6^{\text {th }}$ (edit), Lowa State Univ., Press Ames, Lowa. USA.

Steel, R.G.D. and J, H. Torri (1980). Principles and Procedures of Statistics. A Biometrical Approach, Second Edit. McGrow-Hill Book Co., New York.

Tagnetti. R.M., Pallladina, A. Minnocci, S. Delfine and A. Alvino, (2003). The response of sugar beet to drip and low pressure sprinkler irrigation in Southern Italy. Agric. Water. Manage, 60: 135-155.

Tandon, H.L.S. (1990). Fertilizer recommendation for oil seed crop. A Guide Book, 95pp. Fertilizer Development and Consultation Organization, New Delhi.

Tang, Z.H.A. J. Zhang, M. Wei; X.G. Chen, Z.H. Lui, H.M.Li, and Y.F. Ding, (2015). Physiological response to potassium deficiency in three sweet potato (Pomoea botatos, L.) genotypes differing in potassium utilization efficiency. Acta Phsiol. Plant, 37-189.

Terbea, M. A. V. Vranceamu, E. Percu, D.S. Craiciu, and G. Micut (1995). Physiological response of sunflower plants to drought. Rom Agric. Res., 3: 61-67.

Thakur, D.S. and S.R. Patel (2003). Response of seasame (Sesamum indicum L.) to different level of potassium and Sulphur in light-textured inceptisols of Eastern part of chattisgarh. Indian J. Agric. Sci., 74 (9): 496-498.

Weston, D.J. (1952). The physiological basis of variation in yield. ADv. Agron., 4: 101-145. 


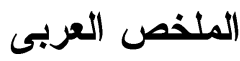

تأثير بعض معدلات الري السطحي ومستويات التسميد البوتاسي على النمو والصفات الفسيولوجية وإنتاجية محصول بنجر العلف تحث ظروف الأراضي الجيرية

مفيدة عبد القادر صيام'، أنجي سمير محد ربيع'، محمود محمد عطيةّ، أحمد محمود عبداللطيف عبد المنعم'

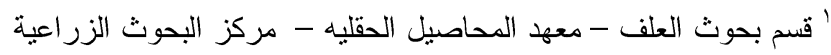

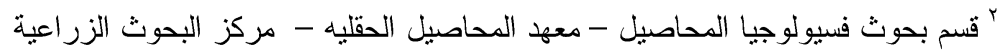

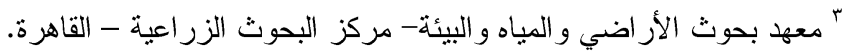

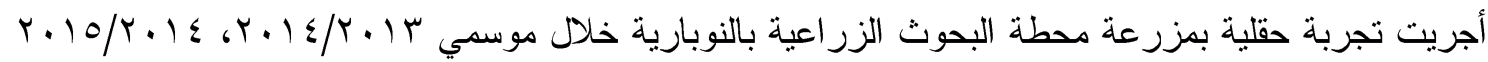

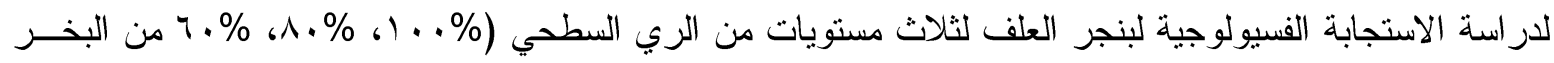

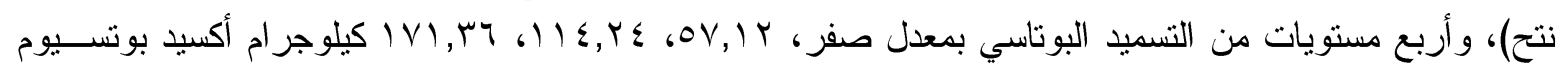

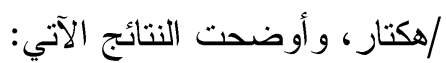

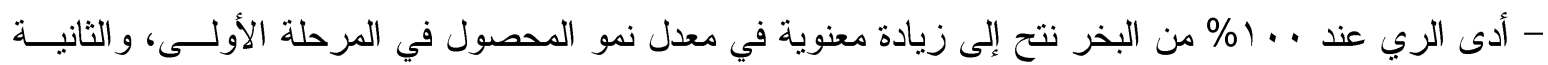

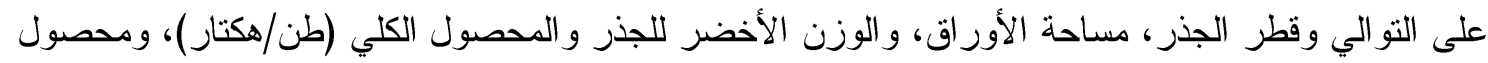

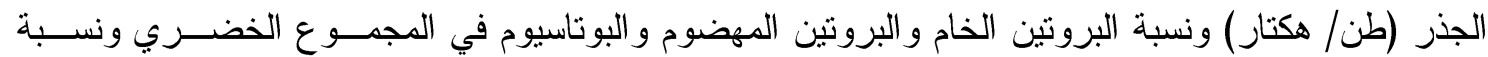
الألباف وكذلك نسبة الكربو هيدرات.

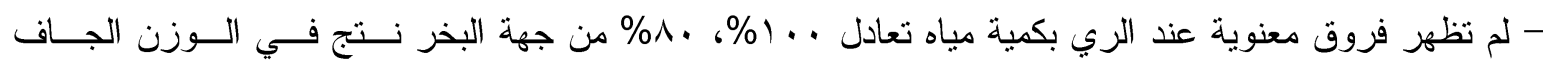
للأور اقوزن العرش (طن/هكتار) وكذللك نسبة البوتاسيوم في الجذور .

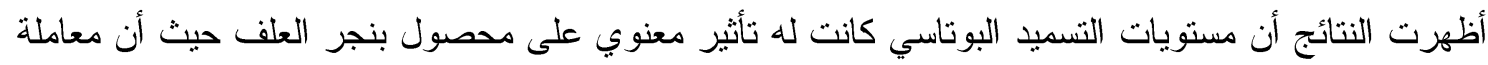

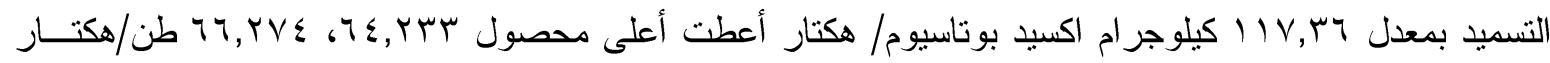

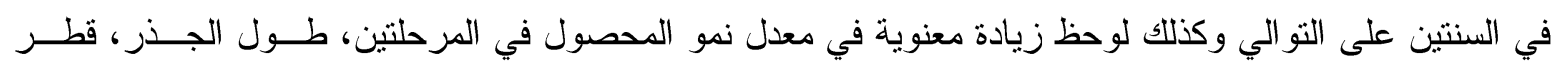

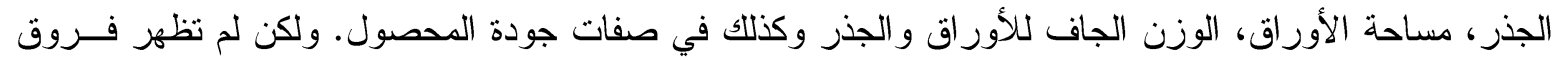

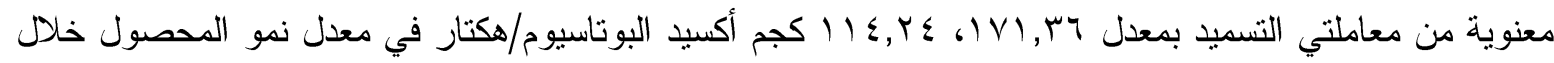
المرحلة الأولى والوزن الأخضر للجذر و العرش ونسبة البوتاسيوم في الجذور والأوراق.

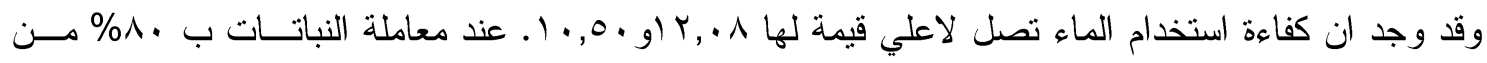

البخر نتح.

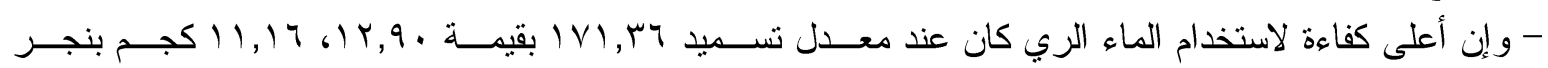

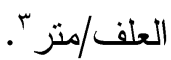

- وجدت أن كفاءة استخدام وحدة المياه المضافة تزيد بزيادة كمية المياه المضافة حتى •^^\% من البخر نتح وتصل

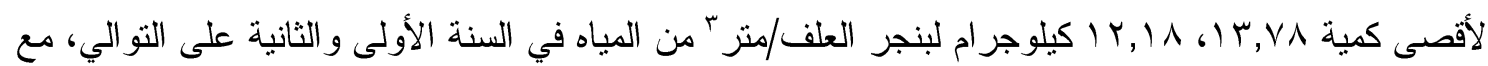

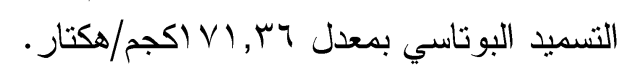

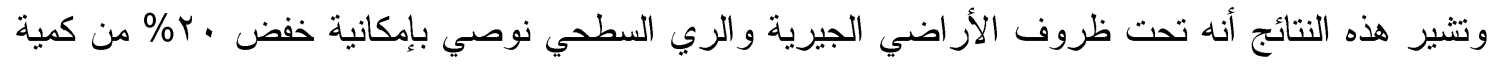

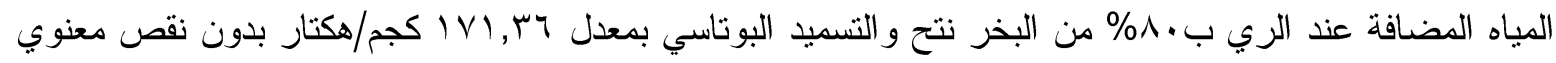
في محصول بنجر العلف. 